This work was supported by research grants from Z.W.O. (Zuiver Wetenschappelijk Onderzoek). We are indebted to "het Openbaar Slachthuis" of Rotterdam for the supplies of calves' and cows' hearts.

J. H. P. JonXIS

Kinderkliniek,

Academisch Ziekenhuis, Groningen.

$$
\text { S. K. WADMAN }
$$

Zuiderziekenhuis, Rotterdam.

Dec. 1.

${ }^{2}$ Pedersen, K, O., "Ultracentrifugal Studies on Serum and Serum Fractions" (Almquist and Wiksells Boktryckeri AB, 1945). 2 Theorell, H., and de Duve, Chr., Arch. Biochem., 12, 113 (1947).

\section{Presence of Organic lodine in the Pituitary}

IN a previous communication in this journal ${ }^{x}$, we reported the evidence from autoradiography for a selective occurrence of organic iodine in the pituitary of guinea pigs injected with a dose of $250 \mu \mathrm{C}$. carrier-free iodine-131. During the past year, we have repeated and extended ${ }^{2}$ our experiments to check a few points which were not clear, namely, the bad reproducibility of the autoradiographs and the lack of agreement with the subsequent findings of other workers ${ }^{3}$.

First we found that, in the conditions of the previous experiments, the radioactivity of the pituitary was very low, about $10^{-5} \mu \mathrm{C}$. per mgm. of tissue; however, this radioactivity did not change if the tissue was treated with the usual histological fixatives and solvents (alcohol formalin, Helly's fluid, xylol). This shows that all the iodine contained in the pituitary is bound in an organic form. The administration of thyreotrophic hormone to the animals after the injection of iodine-131 was found to increase the radioactivity of the pituitary, and we were able to confirm our view that most probably the iodine is present as thyroxine.

Secondly, we obtained positive autoradiographs of pituitary sections provided that, as in the first experiments, the tissue was fixed in Helly's fluid and not protected by a layer of 'Perspex' ; fixation in alcohol as well as in formalin gave us no such images. Since the radioactivity found from our measurements was scarcely sufficient to blacken the emulsion, and this is not affected by alcohol and formalin, it was evident that our previous autoradiographs were due merely to the interaction between the tissue, the Helly's fluid and the emulsion. Our mistake was due to a succession of fortuitous events (some of which are considered in the next paragraph), and so the problem of the localization of the iodine in the pituitary remains open.

We would like to point out that the action of the Helly's fluid is a selective one; thus, the anterior lobe gave a weak but very sharp impression after 21 days exposure, yet the posterior lobe did not. In order to clarify this phenomenon, we studied the action of Helly's fluid on various non-radioactive tissues. We found this fixative always prevented the darkening of the emulsion, except in a few cases in which pseudo-autoradiographs ${ }^{5}$ are still formed; if the section and the superposed emulsion are exposed to a source of radiation, for example, to light, it is possible to accelerate the process of formation of such a pseudo-autoradiographic image. The behaviour of a thyroid section is shown in the accompanying photograph; the autoradiograph is surprisingly similar to a true one, obtained with radioactive iodine. These pseudo-autoradiographs

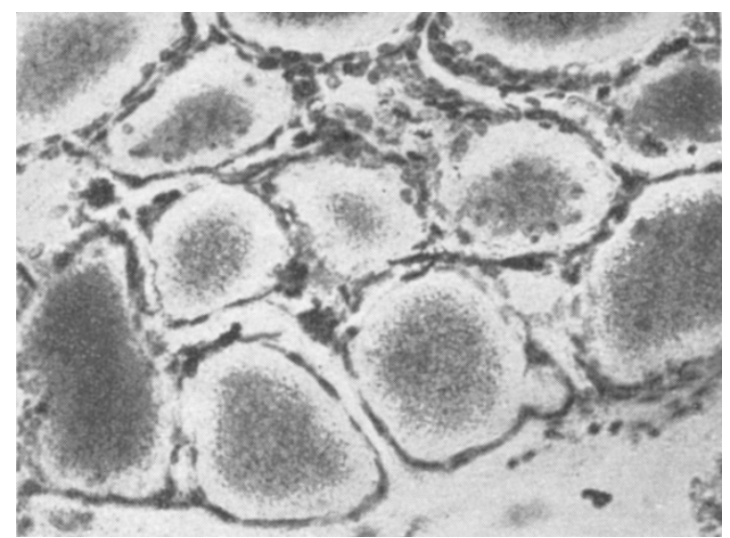

A section of guinea pig thyroid fixed in Helly's fluid; not radioactive. The superposed autoradiographic 5- $\mu$ Kodak emulsion, at the site of the colloid. $\times 200$

are not formed when the tissue is fixed with the most important components of the Helly's fluid ; potassium dichromate just prevents the darkening of the emulsion, and mercuric chloride has no noticeable action. We conclude, therefore, that only the simultaneous action of all the components on the tissue causes the appearance of the pseudo-autoradiograph.

\section{A. Ascenzi}

Istituto di Anatomia e Istologia Patologica dell' Università, Roma.

G. Boato

F. Passalacqua

Istituto di Fisica dell' Università,

Centro di Studio per la Fisica Nucleare del C.N.R., Roma.

Dec. 12.

${ }^{1}$ Ascenzi, A., Boato, G., and Passalacqua, E., Nature, 166, 1069 (1950).

${ }^{2}$ Boato, G., Passalacqua, F., Ascenzi, A., Isotope Techniques Conference, Oxford (1951).

${ }^{3}$ Courrier, R., Horeau, A., Marois, M., and Morel, F., C.R. Acad. Sci. Paris, 232, 776 (1951).

- Blundell, M., and Rotblat, J., Nature, 167, 645 (1951).

- This is an interesting example of an 'autochemograph', a possibility suggested by Boyd, G. A., and Board, F. A., Science, 110, 586 (1949).

\section{Production of Anti-Rh in Guinea Pigs from Human Erythrocyte Extracts}

$\mathrm{I}_{\mathrm{T}}$ was noticed by Lubinski and Portnuff ${ }^{1}$ and others that heat at $50^{\circ} \mathrm{C}$. made $R h$-positive cells suspended in saline become ' $R h$-negative'. Hubinon $t^{2}$ confirmed this observation and pointed out that $R h$-substance could be demonstrated in the supernatant saline by inhibition tests. It seemed that these observations might form the basis of a method for preparing anti- $R h$ sera in animals, if the extracted material were antigenic.

In repeated experiments, good anti- $D$ sera were produced in guinea pigs by the intraperitoneal injection of saline supernatant from heated cells. Some of these sera are still potent after storage for two years at $-20^{\circ} \mathrm{C}$.

By a similar method sera were prepared with saline supernatant from $R h$-negative cells, and with them we could distinguish bloods containing $c$ from those which did not. The immunization to $R h$-negative cell extract was less successful, although the extracts were inhibitory to anti-c, particularly if, in their preparation, slightly greater heat were used for a longer time. 